\title{
Implementai Sekolah Ramah Anak Di SDN Lempuyangwangi Kota Yogyakarta
}

\author{
${ }^{1}$ Tri Utami, ${ }^{2}$ Retno Kusumawiranti, ${ }^{3}$ Matheus Gratiano Mali \\ Program Studi Administrasi Publik, Universitas Widya Mataram \\ triutami.antok@gmail.com, retno_zan@yahoo.co.id, theogratiano_88@yahoo.com
}

\begin{abstract}
Abstraksi.
Penelitian dilatarbelakangi oleh keprihatinan dunia pendidikan terhadap berbagai kasus yang kerap terjadi di sekolah. Dari data KPAI sepanjang Januari hingga April 2019 menyebutkan, pelanggaran hak anak masih terjadi dan didominasi perundungan, yaitu berupa kekerasan fisik, kekerasan psikis, dan kekerasan seksual, dan anak menjadi korban kebijakan. Sekolah Ramah Anak merupakan salah satu kebijakan yang dilakukan sebagai upaya pencegahan dalam mengatasi berbagai permasalahan yang melanggar hak anak terutama ketika berada di sekolah. SDN Lempuyangwangi adalah salah satu sekolah di Kota Yogyakarta yang menerapkan kebijakan Sekolah Ramah Anak (SRA) ini. Penelitian ini bertujuan untuk mendeskripsikan implementasi Program Sekolah Ramah Anak di SD Negeri Lempuyangwangi Kota Yogyakarta. Deskripsi tersebut terkait dengan implementasi Program Sekolah Ramah Anak serta faktor-faktor yang mempengaruhi dalam mengimplementasikan Program Sekolah SRA. Penelitian ini menggunakan jenis penelitian deskriptif kualitatif. Subjek dalam penelitian ini yaitu tim Sekolah Ramah Anak Kota Yogyakarta, kepala sekolah, guru, siswa, dan orang tua siswa dengan objek penelitian meliputi implementasi Program Sekolah Ramah Anak di SD Negeri Lempuyangwangi. Metode pengumpulan data yang digunakan berupa wawancara mendalam (Indepth Interview), observasi, dan dokumentasi. Teknik analisis data menggunakan model interaktif Miles dan Huberman meliputi pengumpulan data, reduksi data, penyajian data, dan verifikasi/penarikan kesimpulan. Adapun validasi data menggunakan triangulasi sumber data. Dari hasil penelitian terlihat bahwa: (1)Komitmen tertulis tentanf kebijakan tentang Sekolah Ramah Anak sudah ada; (2) metode pembelajaran berbasis PAIKEM (Pembelajaran Aktif, Inovatif, Kreatif, Efektif, dan Menyenangkan) sudah sesuai dengan prinsip SRA; (3) partisipasi anak sudah baik terlihat pada peran siswa dalam keaktifannya berekspresi, bertanya, menjawab, berargumentasi, dan memberikan interupsi; dan (4) Partisipasi orang tua, lembaga masyarakat, dunia usaha, pemangku kepentingan sudah terjalin dengan baik. Faktor yang mempengaruhi implementasi SRA di SD Negeri Lempuyangwangi meliputi: (1) Komunikasi, (2) Sumber daya manusia, sumber daya sarana prasarana dan metode yang digunakan untuk pencapaian Sekolah Ramah Anak; dan (3) Disposisi. Hasil penelitian menunjukkan bahwa program Sekolah Ramah Anak (SRA) di SDN Lempuyangwangi telah terimplikasikan dengan baik. Namun masih perlu perbaikan di bidang sarana dan prasarana serta belum terpenuhonya guru bimbingan konseling dan guru untuk ank berkebutuhan khusus (inklusi).
\end{abstract}

\section{Kata kunci: Implementasi, Sekolah Ramah Anak, SD Negeri Lempuyangwangi}

\begin{abstract}
.
This research is lead by the concern education institutions towards various violations of children's rights cases that often occur in schools. KPAI is stated that violations of children's rights still occur and are dominated by bullying, namely in the form of physical violence, psychological violence, and sexual violence, and children are victims of policies from January to April 2019 . Child Friendly School is one of the policies implemented as a prevention effort in overcoming various problems that violate children's rights, especially when they are in school. SDN Lempuyangwangi is one of the schools in Yogyakarta City that implements this Child Friendly School (SRA) policy. This study aims to describe the implementation of the Child Friendly School Program at SD Negeri Lempuyangwangi in Yogyakarta City. This research uses descriptive qualitative research. The subjects in this study were the Yogyakarta City Child Friendly School team, principals, teachers, students, and parents with the object of research covering the implementation of the Child Friendly School Program at SD Negeri Lempuyangwangi. Data collection methods used in the form of in-depth interviews (Indepth Interview), observation, and documentation. Data analysis techniques using Miles and Huberman's
\end{abstract}


interactive model include data collection, data reduction, data presentation, and verification/drawing conclusions. The data validation uses data source triangulation.From the results of the study, it can be seen that: (1) A written commitment to policies regarding Child Friendly Schools already exists; (2) PAIKEM-based learning methods (Active, Innovative, Creative, Effective, and Fun Learning) are in accordance with SRA principles; (3) children's participation has been well seen in the role of students in their activeness in expressing, asking, answering, arguing, and giving interruptions; and (4) The participation of parents, community institutions, the business world, stakeholders has been well established. Factors influencing the implementation of SRA in SD Negeri Lempuyangwangi include: (1) Communication, (2) human resources, infrastructure resources and methods used to achieve Child Friendly Schools; and (3) Disposition.The results showed that the Child Friendly School (SRA) program at SDN Lempuyangwangi had been well implied. However, improvements are still needed in the field of facilities and infrastructure as well as the lack of fulfillment of guidance and counseling teachers and teachers for children with special needs (inclusion).

Keywoords : Implementation, Child Friendly School SD Negeri Lempuyangwangi.

\section{Pendahuluan.}

Perlindungan anak mutlak diwujudkan oleh setiap elemen masyarakat dan tentunya dijamin keberadaannya oleh negara agar anak dapat tumbuh dan berkembang secara wajar. Sesuai dengan Undang-Undang No.23 Tahun 2002 tentang Perlindungan Anak, perlindungan anak mencakup anak yang belum berusia 18 tahun, termasuk anak yang masih dalam kandungan, dan meliputi hak-hak anak untuk hidup, tumbuh, berkembang, dan berpartisipasi dalam berbagai aspek kehidupan serta mendapat perlindungan dari berbagai bentuk kekerasan dan diskriminasi. Pada tahun 2011, Kementerian Negara Pemberdayaan Perempuan dan Perlindungan Anak (Kemenneg PPPA) menginisiasikankan Kabupaten/KotaLayak Anak (KLA) sebagai suatu sistem pembangunan berbasis hak anak dilevel kabupaten atau Kota, melalui pengintegrasian komitmen dan sumber daya pemerintah, masyarakat maupun dunia usaha yang terencana secara menyeluruh dan berkelanjutan dalam kebijakan, program, dan kegiatan untuk menjamin terpenuhinya hak anak (Peraturan Menteri Negara Pemberdayaan Perempuan dan Perlindungan Anak No. 11 Tahun 2011).

Namun dalam pelaksanaannya kebijakan tersebut dinilai masih tergolong rendah, ini terlihat dari berbagai temuan tentang permasalahan mengenai anak yang belum teratasi. Menurut data KPAI sepanjang Januari hingga April 2019 menyebutkan, pelanggaran terhadap hak anak masih banyak terjadi dan sangat didominasi oleh perundungan, yaitu berupa kekerasan fisik, kekerasan psikis, dan kekerasan seksual, dan anak menjadi korban kebijakan. Terdapat sebanyak delapan kasus kejadian anak korban kebijakan yaitu pemberian sanksi yang memalukan, anak yang tidak mendapatkan surat pindah, anak tidak dapat mengikuti ujian, anak dikeluarkan dari sekolah karena terlibat tawuran, anak dieksploitasi di sekolah, anak ditolak karena mengidap HIV/AIDS, dan anak yang dikeluarkan karena menjadi korban kekerasan seksual.

Menyandang predikat sebagai Kota Layak Anak (KLA) merupakan suatu kebanggaan bagi Kota Yogyakarta namun sekaligus menjadi tantangan bagi pemerintah Kota Yogyakarta. Agar benar-benar dapat menjadi Kota Layak Anak, sesuai yang diamanatkan dalam Peraturan Menteri Pemberdayaan Perempuan dan Perlindungan Anak Nomor 12 Tahun 2011 tentang Indikator Kabupaten/Kota Layak Anak, salah satunya adalah adanya instrumen hukum daerah yang menjamin pemenuhan hak-hak anak. Oleh karena itu Pemerintah Kota Yogyakarta menetapkan Peraturan Daerah Kota Yogyakarta Nomor 1 Tahun 2016 tentang Kota Layak Anak. Dalam Perda Kota Yogyakarta Nomor 1 Tahun 2016 tersebut disebutkan bahwa Kebijakan Kota Layak Anak diarahkan pada pemenuhan hak anak yang salah satunya melalui pengembangan Sekolah Ramah Anak (SRA). Melalui Sekolah Ramah Anak 
diharapakan anak-anak dapat terpenuhi hak-haknya dalam bidang pendidikan. Menindaklanjuti hal tersebut, Pemerintah Kota Yogyakarta segera membuat dan mengesahkan Peraturan Walikota Yogyakarta no 49 tahun 2016 tentang Sekolah Ramah Anak (SRA). Hal ini dilakukan sebagai pedoman dalam mempermudah dan mempercepat terwujudnya sekolah yang ideal sebagaimana yang telah direncanakan. Sekolah Ramah Anak sangat diharapkan dapat menjadi institusi yang mengenal dan menghargai hak anak untuk memperoleh pendidikan, kesehatan, kesempatan bermain dan bersenang, melindungi dari kekerasan dan pelecehan, dapat mengungkapkan pandangan secara bebas, dan berperan serta dalam mengambil keputusan sesuai dengan kapasitas mereka. Sekolah juga dapat menanamkan tanggung jawab untuk menghormati hak-hak orang lain, kemajemukan dan menyelesaikan masalah perbedaan tanpa melakukan kekerasan. Mulai dari sosialisasi, penyusunan kebijakan, konsultasi, pembentukan Tim Pelaksana, bahkan identifikasi potensi, kerjasama dari seluruh pemangku kepentingan dan pemenuhan sarana prasarana menjadi penunjang keberhasilan persiapan SRA. Anak sebagai peserta didik yang merupakan alasan satu-satunya mengapa SRA diselenggarkan tentunya menjadi kunci keberhasilan SRA. Oleh karenanya, partisipasi dari anak dalam setiap bagian dalam tahap persiapan SRA menjadi komponen wajib dan penting. Para pendidik dan tenaga kependidikan di sekolah diharapkan menyelenggarakan pendidikan dan pembelajaran yang mampu memfasilitasi peserta didik berperilaku terpelajar.

Sekolah Dasar Negeri Lempuyangwangi, adalah salah satu sekolah di Kota Yogyakarta yang sejak tahun 2017 mulai menerapkan kebijakan Sekolah Ramah Anak (SRA). Sekolah ini telah berupaya menjamin dan memenuhi hak-hak anak dalam setiap aspek kehidupan secara terencana dan bertanggung jawab. Programnya diutamakan dalam mengedepankan kegiatan yang bersifat partisipatif untuk seluruh siswa sehingga hak-hak mereka lebih terlindungi dalam kegiatan belajar mengajar di sekolah. Dalam proses pelaksanaannya, program Sekolah Ramah Anak ini sendiripun masih mengalami kendala. Hal ini dikarenakan untuk mewujudkan SRA dan mengimplementasikannya di sekolah masih memerlukan berbagai persiapan. Pengelolaan SRA di sekolah sangat tidak terlepas dari peran guru, orang tua, dan peserta didik. Kerja sama yang baik perlu dilakukan oleh ketiga elemen penting dalam pendidikan ini.

\section{Metode.}

Pendekatan penelitian yang digunakan dalam penelitian ini adalah penelitian kualitatif. Penelitian kualitatif adalah penelitian yang bermaksud untuk memahami fenomena tentang apa yang dialami oleh subjek penelitian secara holistik dan dengan cara deskripsi dalam bentuk kata-kata dan bahasa, pada suatu konteks khusus yang alamiah dan dengan memanfaatkan berbagai metode ilmiah (Moloeng, 2007: 6). Pengamatan akan dilakukan secara langsung tanpa memberi perlakuan yaitu terhadap pemahaman perangkat sekolah mengenai Sekolah Ramah Anak pada SD Negeri Lempuyangwangi Yogyakarta. Peneliti juga melakukan penelitian terhadap pemahaman perangkat sekolah mengenai Sekolah Ramah Anak yakni kepala sekolah, guru, karyawan, orang tua siswa, siswa dan komite sekolah.

Data penelitian ini berasal dari data primer dan data sekunder. Pengumpulan data dalam penelitian ini dilakukan dengan menggunakan tiga metode yakni wawancara mendalam (Indepth Interview), observasi dan dokumentasi. Penentuan sumber data dipertimbangkan terlebih dahulu, bukan diacak. Artinya menentukan informan sesuai dengan kriteria terpilih yang relevan dengan masalah penelitian.

Dalam penelitian ini pengujian kredibilitas data dilakukan dengan triangulasi sumber data. Triangulasi sumber data berarti membandingkan dan mengecek ulang derajat kepercayaan suatu informasi yang diperoleh melalui sumber yang berbeda. Peneliti akan membandingkan data hasil pengamatan dengan data hasil wawancara dan 
dokumen-dokumen yang berkaitan. Analisis data dalam penelitian ini menggunakan teori Miles dan Hubermen meliputi reduksi data (data reduction), penyajian data (data display) serta penarikan kesimpulan dan verifikasi (conclusion drawing/verification).

\section{Hasil Dan Pembahasan}

\section{Penetapan sekolah ramah anak}

Penetapan sekolah ramah anak didasarkan pada kemampuan sekolah dalam menjamin pemenuhan hak anak dalam proses belajar mengajar, aman, nyaman, bebas dari kekerasan dan diskriminasi, serta menciptakan ruang bagi anak untuk belajar berinteraksi, berpartisipasi, bekerjasama, menghargai keberagaman, toleransi dan perdamaian.

Sekolah ramah anak sekurang-kurangnya memenuhi ketentuan:

a. mempunyai kebijakan yang anti terhadap segala bentuk atau jenis kekerasan, penindasan, penggencetan, perpeloncoan, pemalakan, pengucilan, atau intimidasi yang mengatur sesama siswa, tenaga pendidik dan kependidikan, termasuk pegawai sekolahlainnya;memiliki program Usaha Kesehatan Sekolah (UKS);

b. mempunyai lingkungan sekolah yang bersih dan sehat;

c. menerapkan Perilaku Hidup Bersih Sehat (PHBS);

d. termasuk Sekolah segala Adiwiyata;

e. memiliki Warung / Kantin Kejujuran dan sehat atau aktifitas perdagangan yang serupa; dan siswa terlibat/dilibatkan dalam pembuatan kebijakan sekolah

Hasil yang diharapkan dari terlaksananya Sekolah Ramah Anak :

a) Mewujudkan sekolah yang aman dan menyenangkan bagi peserta didik karena bebas dari kekerasan antar peserta didik maupun kekerasan yang dilakukan oleh pendidik dan tenaga kependidikan;

b) Membentuk perilaku pendidik dan tenaga kependidikan yang berprespektif anak;

c) Menerapkan disiplin positif yang membantu anak untuk berfikir dan bertindak benar untuk anak yang dianggap melalaikan kewajibannya bukan berupa sanksi atau hukuman yang selama ini sering dilakukan.

d) Meningkatkan partisipasi peserta didik dalam melaksanakan proses pembelajaran dan dalam pengambilan keputusan di sekolah.

Ketentuan lebih lanjut tentang Sekolah Ramah Anak tersebut diatur dalam Kebijakan Peraturan Walikota. Dari isi yang terkandung dalam Peraturan Daerah Kota Yogyakarta Nomor 1 Tahun 2016 tentang Kota Layak Anak di atas bisa dilihat bahwa peraturan ini menjadi salah satu dasar diterapkannya Kebijakan Sekolah ramah Anak (SRA) di Kota Yogyakarta. Selain itu, Pembentukan Tim Pelaksana menjadi bagian yang sangat krusial. Dalam panduan yang diterbitkan oleh KP3A tercantum bahwa Pembentukan Tim SRA di Satuan Pendidikan yang berasal dari unsur Kepala Sekolah/Madrasah, Wakil Guru, Wakil Guru BK, Wakil OSIS, Wakil peserta didik dari setiap jenjang kelas, wakil dari Komite Sekolah/madrasah, wakil dari persatuan Orang Tua/Wali atau dapat ditambahkan juga wakil dari alumni.

Dalam Surat Keputusan tersebut termuat Tim Gugus Tugas Sekolah Ramah Anak SDN Lempuyangwangi. Sesuai dengan panduan yang diterbitkan oleh KPPPA bahwa Pembentukan Tim SRA di Satuan Pendidikan berasal dari unsur Kepala Sekolah/Madrasah, Wakil Guru, Wakil Guru BK, Wakil OSIS, Wakil peserta didik dari setiap jenjang kelas, wakil dari Komite Sekolah/madrasah, wakil dari persatuan Orang Tua/Wali atau dapat ditambahkan juga wakil dari alumni.

Berikut adalah SOP (Standard Operating Procedure) yang digunakan dalam pembentukan Tim Gugus Tugas Sekolah Ramah Anak yang termuat dalam Surat Keputusan Kepala Sekolah SDN Lempuyangwangi. 
Tabel SOP Pembentukan Tim Gugus SRA

\begin{tabular}{|c|c|c|c|c|c|}
\hline \multirow{2}{*}{ No } & \multirow{2}{*}{ Kegiatan } & \multirow{2}{*}{ Pelaksana } & \multicolumn{3}{|l|}{ Mutu Baku } \\
\hline & & & Kelengkapan & Waktu & Output \\
\hline 1 & $\begin{array}{l}\text { Rapat } \\
\text { Membentuk } \\
\text { Tim gugus } \\
\text { SRA }\end{array}$ & $\begin{array}{l}\text { Kepala } \\
\text { Sekolah, } \\
\text { Guru, } \\
\text { Komite, } \\
\text { Tata Usaha, } \\
\text { Orangtua } \\
\text { siswa, } \\
\text { Siswa }\end{array}$ & $\begin{array}{l}\text { Format Tim } \\
\text { gugus SRA }\end{array}$ & $1 \mathrm{Jam}$ & $\begin{array}{l}\text { Format } \\
\text { Pembentuk } \\
\text { an Tim } \\
\text { gugus SRA }\end{array}$ \\
\hline 2 & $\begin{array}{l}\text { Pembuatan } \\
\text { SK Tim } \\
\text { gugus SRA }\end{array}$ & $\begin{array}{l}\text { Kepala } \\
\text { Sekolah }\end{array}$ & $\begin{array}{lr}\text { Format } & \text { SK } \\
\text { Tim gugus } \\
\text { SRA } \\
\text { dikumpulkan }\end{array}$ & 30 Menit & $\begin{array}{l}\text { Hasil } \\
\text { Pembentuk } \\
\text { an gugus } \\
\text { Tim SRA }\end{array}$ \\
\hline 3 & $\begin{array}{l}\text { Membuat } \\
\text { konsep } \\
\text { pelaksanaan } \\
\text { SRA }\end{array}$ & $\begin{array}{l}\text { Kepala } \\
\text { Sekolah, } \\
\text { Guru, } \\
\text { Komite, } \\
\text { Tata Usaha, } \\
\text { Orangtua } \\
\text { siswa, } \\
\text { Siswa }\end{array}$ & $\begin{array}{l}\text { Hasil olahan } \\
\text { format SRA }\end{array}$ & $1 \mathrm{Jam}$ & $\begin{array}{l}\text { Konsep } \\
\text { laporan }\end{array}$ \\
\hline 4 & $\begin{array}{l}\text { Memeriksa } \\
\text { hasil format } \\
\text { SRA }\end{array}$ & $\begin{array}{l}\text { Kepala } \\
\text { Sekolah }\end{array}$ & $\begin{array}{l}\text { Konsep } \\
\text { laporan }\end{array}$ & 1 Hari & $\begin{array}{l}\text { Laporan } \\
\text { telah } \\
\text { diperiksa } \\
\text { dan } \\
\text { ditandatang } \\
\text { ani }\end{array}$ \\
\hline 5 & $\begin{array}{l}\text { Laporan } \\
\text { telah } \\
\text { diperiksa dan } \\
\text { ditandatanga } \\
\text { ni }\end{array}$ & $\begin{array}{l}\text { Kepala } \\
\text { Sekolah }\end{array}$ & $\begin{array}{l}\text { Laporan telah } \\
\text { diperiksa dan } \\
\text { ditandatangani }\end{array}$ & 1 Hari & $\begin{array}{l}\text { Laporan } \\
\text { dalam } \\
\text { bentuk } \\
\text { print out } \\
\text { dan soft file }\end{array}$ \\
\hline 6 & $\begin{array}{l}\text { Mengirim } \\
\text { laporan ke } \\
\text { UPT/Disdik }\end{array}$ & Tata Usaha & $\begin{array}{l}\text { Laporan telah } \\
\text { digandakan } \\
\text { dan dijilid }\end{array}$ & 1 Hari & $\begin{array}{l}\text { Tanda } \\
\text { terima } \\
\text { laporan } \\
\text { pengiriman }\end{array}$ \\
\hline
\end{tabular}

Sumber : SOP Pembentukan Tim SRA SDN Lempuyangwangi

\section{Implementasi Kebijakan Sekolah Ramah Anak (SRA) di SD Negeri Lempuyangwangi Yogyakarta}

Implementasi Kebijakan Sekolah Ramah Anak (SRA) di SD Negeri Lempuyangwangi Yogyakarta terlihat dari beberapa berikut :

a. Adanya Komitmen Tertulis yang Dapat Dianggap Kebijakan Tentang Sekolah Ramah Anak

\section{a.1. Panduan Sekolah Ramah Anak (SRA)}

Paduan Sekolah Ramah Anak ini dikeluarkan oleh Deputi Tumbuh Kembang Anak Kementrian Pemberdayaan Perempuan dan Perlindungan Anak tahun 2015. Isi dari panduan ini antara lain: Sekolah Ramah Anak (SRA) lahir dari adanya amanat yang harus diselenggarakan Negara untuk memenuhi hak anak sebagaimana tercantum dalam Konvensi Hak Anak yang telah di ratifikasi Indonesia pada Tahun 1990, serta adanya 
tuntutan dari Undang-undang Nomor 23 Tahun 2003 tentang Perlindungan Anak dan Undang-Undang Nomor 35 Tahun 2014 tentang Perubahan atas Undang- Undang Nomor 23 Tahun 2003 tentang Perlindungan Anak yang jelas pada pasal 54. Selain itu disusunnya Kebijakan Sekolah Ramah Anak bertujuan untuk dapat memenuhi, menjamin dan melindungi hak anak, serta memastikan bahwa satuan pendidikan mampu mengembangkan minat, bakat dan kemampuan anak serta mempersiapkan anak untuk bertanggung jawab kepada kehidupan yang toleran, saling menghormati, dan bekerjasama untuk kemajuan dan semangat perdamaian.

Selain itu adalah Konsep Sekolah Ramah Anak didefinisikan sebagai program untuk mewujudkan kondisi aman, bersih, sehat, peduli, dan berbudaya lingkungan hidup, yang mampu menjamin pemenuhan hak dan perlindungan anak dari kekerasan, diskriminasi, dan perlakuan salah lainnya, selama anak berada di satuan pendidikan, serta mendukung partisipasi anak terutama dalam perencanaan, kebijakan, pembelajaran dan pengawasan.

\section{a.2. Peraturan Daerah Kota Yogyakarta Nomor 1 Tahun 2016 Tentang Kota Layak Anak}

Selanjutnya berkembang berbagai inisiatif upaya pengembangan KLA baik dari Pemerintah Daerah, masyarakat maupun lembaga masyarakat untuk menyambut kebijakan Kota Layak Anak (KLA) yang telah dirumuskan oleh Pemerintah Pusat, di Kota Yogyakarta telah. Upaya bersama antara Pemerintah Daerah, orang tua, keluarga, masyarakat, dan dunia usaha untuk menjamin pemenuhan hak anak sangat diperlukan untuk pengembangan Kota Layak Anak di Kota Yogyakarta. Serta semakin menguatkan dasar pembentukan Peraturan Daerah Kota Layak ini melalui urusan pemerintahan di bidang perlindungan anak berupa kebijakan, program, dan kegiatan untuk menjamin terpenuhinya hak anak agar anak dapat hidup, tumbuh, berkembang, dan berpartisipasi secara optimal sesuai dengan harkat dan martabat kemanusiaan, serta mendapat perlindungan dari kekerasan dan diskriminasi, yang merupakan urusan wajib pemerintahan daerah.

\section{a.3. Peraturan Walikota Yogyakarta No. 49 Tahun 2016 Tentang Sekolah Ramah Anak}

Dalam Pasal 40 ayat (3) Peraturan Daerah Kota Yogyakarta Nomor 1 Tahun 2016 tentang Kota Layak Anak disebutkan bahwa ketentuan lebih lanjut tentang Sekolah Ramah Anak diatur dalam Peraturan Walikota. Untuk menindaklanjuti hal tersebut maka ditetapkan Peraturan Walikota Yogyakarta No. 49 Tahun 2016 Tentang Sekolah Ramah Anak. Dalam Perwal ini dimuat antara lain ketentuan, prinsip, tujuan, tahapan pembentukan, pengawasan serta evaluasi tentang Sekolah Ramah Anak.

\section{a.4. Surat Keputusan Kepala Sekolah SDN Lempuyangwangi tentang Pembentukan Tim Sekolah Ramah}

Pembentukan Tim Pelaksana menjadi bagian yang sangat krusial. Dalam panduan yang diterbitkan oleh KP3A tercantum bahwa Pembentukan Tim SRA di Satuan Pendidikan yang berasal dari unsur Kepala Sekolah/Madrasah, Wakil Guru, Wakil Guru BK, Wakil OSIS, Wakil peserta didik dari setiap jenjang kelas, wakil dari Komite Sekolah/madrasah, wakil dari persatuan Orang Tua/Wali atau dapat ditambahkan juga wakil dari alumni.

Dalam Surat Keputusan tersebut termuat Tim Gugus Tugas Sekolah Ramah Anak SDN Lempuyangwangi. Sesuai dengan panduan yang diterbitkan oleh KPPPA bahwa Pembentukan Tim SRA di Satuan Pendidikan berasal dari unsur Kepala Sekolah/Madrasah, Wakil Guru, Wakil Guru BK, Wakil OSIS, Wakil peserta didik dari setiap jenjang kelas, wakil dari Komite Sekolah/madrasah, wakil dari persatuan Orang Tua/Wali atau dapat ditambahkan juga wakil dari alumni.

\section{a.5. Komitmen tertulis Internal sekolah yang mendukung SRA}




\section{Deklarasi Sekolah Ramah Anak}

Komitmen tentang pemenuhan dan perlindungan anak di satuan pendidikan perlu diperkuat dengan menyusun kebijakan tentang pelaksanaan SRA di masing-masing satuan pendidikan. Penyusunan kebijakan tentang pelaksanaan SRA ini juga bertujuan untuk membangun komitmen bersama antar warga sekolah untuk membentuk atau mengembangkan SRA sebagai kebutuhan bersama, serta menuangkan komitmen tersebut sebagai landasan dalam pelaksanaan kebijakan SRA di sekolah, agar dapat berjalan dengan maksimal dan sesuai dengan yang diharapkan.

2. Pakta Integritas Sekolah Ramah Anak

Pakta integritas adalah dokumen yang berisi pernyataan atau janji kepada diri sendiri tentang komitmen melaksanakan seluruh tugas, fungsi, tanggung jawab, wewenang dan peran sesuai dengan peraturan perundang-undangan dan kesanggupan untuk tidak melakukan korupsi, kolusi dan nepotisme (Pasal 1 angka 1 Permen PANRB 49/2011). Kebijakan SRA berkaitan langsung dengan pakta integritas dalam mencegah kekerasan terhadap anak.

3. Dokumen yang memuat upaya untuk melaksanakan kebijakan anti kekerasan.

Dari observasi yang dilakukan oleh peneliti, didapati beberapa dokumen tertulis yang mendukung pelaksanaan SRA antara lain:

a) Adanya tata tertib bagi siswa serta kode etik guru, sebagai salah satu upaya untuk penegakan disiplin dengan non kekerasan (disiplin positif)

b) Pengintegrasian materi kesehatan, lingkungan hidup, dan pengurangan resiko kebencanaan di dalam materi pembelajaran.

c) Komitmen untuk mewujudkan kawasan tanpa rokok dan Napza, salah satunya diwujudkan dengan pemasangan spanduk kawasan bebas rokok

d) SOP (Standard Operating Procedure) pengaduan dan penanganan siswa yang bermasalah.

e) Mewajibkan orang tua untuk melaporkan riwayat medis anaknya pada saat penerimaan murid baru dan diupdate setiap tahun dalam data pokok pendidikan (Dapodik) untuk deteksi dini dan pencegahan.

\section{Pelaksanaan proses pembelajaran yang ramah anak}

\section{a. Penerapan Pembelajaran Berbasis PAIKEM}

Istilah PAIKEM merupakan singkatan dari pembelajaran Aktif, Inovatif, Kreatif, Efektif, dan Menyenangkan. Model pembelajaran PAIKEM ini telah diterapkan di SD Negeri Lempuyangwangi sekaligus untuk mendukung program Sekolah Ramah Anak. Hal ini sesuai dengan kurikulum yang digunakan yaitu Kurikulum 2013 yang lebih banyak mendorong kreatifitas siswa dalam belajar.

Salah satu dari delapan standar nasional pendidikan tersebut adalah standar proses yakni proses pembelajan interaktif, inspiratif, menyenangkan, menantang, memotivasi peserta didik untuk berperan aktif, memberikan ruang yang cukup bagi prakarsa, kreativitas, dan kemandirian sesuai dengan bakat, minat, perkembangan fisik serta psikologis peseta didik yang dalam pengimplementasian pembelajaran di dalam kelas menggunakan pendekatan saintifik yang berbasis PAIKEM. Implementasi dari metode pembelajaran PAIKEM sebagai berikut:

1. Pembelajaran Aktif

Active learning adalah sebuah usaha dalam kegiatan pembelajaran yang mencoba membangun keaktifan peserta didik selama proses pembelajaran dimana menekankan keterlibatan seluruh indra. Kegiatan pembelajran dilakukan dengan banyak memberi tugas, memperlajari gagasan dan memecahkan masalah yang diberikan untuk memaksimalkan otak untuk menerapkan apa saja yang dipelajarinya. 
Tugas pendidik bukan hanya untuk menyampaikan materi saja selama proses pembelajaran, namun juga mampu menciptakan kondisi sebagaimana mestinya agar selama proses pembelajaran peserta didik dapat terkondisikan dengan baik untuk mendapatkan materi yang dipelajarinya sehingga dapat mencapai tujuan pembelajaran yang sudah ditetapkan sebelumnya. Keaktifan siswa terlihat dari banyaknya kunjungan siswa ke perpustakaan untuk membaca dan meminjam buku guna menyelesaikan tugas-tugas dari guru. Selain itu siswa juga aktif mengikuti berbagai perlombaan, baik yang diadakan oleh instansi pemerintah maupun swasta.

2. Pembelajaran Inovatif

Pembelajaran inovatif adalah pembelajaran yang dikemas oleh pembelajar atas dorongan gagasan barunya yang merupakan produk dari learning how to learn untuk melakukan langkah-langkah belajar, sehingga memperoleh kemajuan hasil belajar. Kegiatan-kegiatan pembelajaran inovatif yang telah diterapkan meliputi: Penyampaian materi menggunakan layar LCD agar siswa lebih mudah menangkap materi pembelajaran dan Menggunakan alat peraga

3. Pembelajaran Kreatif, Efektif dan Menyenangkan

Kegiatan belajar mengajar di SDN Lempuyangwangi tidak hanya dilakukan di dalam kelas saja, namun siswa diajak untuk mengeksplorasi pengetahuan lewat benda-benda yang nyata, agar pemahaman siswa lebih mendalam serta menciptakan suasana belajar yang menyenangkan. Beberapa kegiatan luar sekolah yang dilaksakan antara lain:

a) Pengenalan Lingkungan Sekolah (PLS)

Kegiatan Pengenalan Lingkungan Sekolah ini diperuntukkan bagi siswa baru kelas satu. Mereka diajak untuk keliling lingkungan sekolah untuk mengenalkan tempat-tempat yang ada di lingkungan sekolah seperti ruang kepala sekolah, ruang guru, ruang tata usaha, ruangruang kelas, kantin, kamarmandi/WC, perpustakaan, ruang UKS, laboratorium komputer, ruang musik, tempat parkir, musholla sekolah dan ruangan-ruangan lain yang ada di lingkungan sekolah.

b) Kunjung Museum

Kegiatan kunjung museum dilaksanakan bergiliran setiap paralel kelas. Kegiatan ini bekerja sama dengan pihak pengelola museum, orang tua siswa dan pihak sekolah. Pembiayaan untuk tiket masuk dan biaya pembelajaran ditanggung oleh sekolah melalui dana Bantuan Operasional Sekolah (BOS), namun untuk biaya konsumsi, transportasi dan biaya pribadi lainnya dibebankan kepada orang tua melalui musyawarah dan kesepakatan bersama.

c) Outbound dan Outing Class

Dari hasil observasi yang dilakukan peneliti di dokumen kegiatan pembelajaran disebutkan bahwa tujuan kegiatan ini adalah Melatih percaya diri, Membiasakan Kerja Sama, Melatih komunikasi, Terhindar dari kecanduan gadged, Menumbuhkan sifat kepemimpinan, Lebih menghargai alam, Menjadi lebih disiplin dan bertanggungjawab, Anak terpacu untuk kreatif.

d) Kunjungan ke panti asuhan dan panti wreda.

Kunjungan ke panti asuhan merupakan kunjungan rutin yang dilakukan oleh siswa- siswi kelas VI sebagai bagian dari kegiatan persiapan menghadapi Ujian. Diharapkan dengan kunjungan ini anak-anak yang akan melaksanakan ujian menjadi lebih termotivasi dan membesarkan mental mereka. Acara kunjungan ini antara lain meminta doa dari anak-anak yatim piatu serta ada siraman rohani dan motivasi yang disampaikan oleh pengurus panti asuhan.

e) Gerakan Literasi Sekolah (GLS) Outdoor

GLS diterapkan di SDN Lempuyangwangi sejak tahun ajaran 2018/2019. Sehingga tahun ajaran 2020/2021 merupakan tahun ketiga diselenggarakannya GLS. SDN Lempuyangwangi menetapkan kebijakan bahwa kegiatan GLS merupakan kegiatan sekolah, dengan demikian seluruh komponen sekolah turut melaksanakan kegiatan GLS tersebut. Sebagai akibat dari 
kebijakan tersebut, maka sekolah menyiapkan perangkat yang diperlukan untuk pelaksanaan GLS seperti melengkapi perpustakaan, meletakkan rak buku di tempat strategis dan di beberapa sudut sekolah agar siswa dapat membaca kapanpun, dan menyediakan perpustakaan di tiap kelas. Untuk ini, Kepala Sekolah menunjuk seorang guru sebagai koordinator GLS untuk menyiapkan sarana dan prasarana, membuat jadwal, dan membuat kebijakan.

\section{Prinsip Pembelajaran Ramah Anak yang diterapkan di SDN Lempuyangwangi}

Pembelajaran yang berlangsung di ruang kelas sesungguhnya sebuah interaksi yang bersifat dinamis. Ada interaksi guru dengan siswa, siswa dengan temannya dan siswa dengan sumber belajar. Interaksi yang terjadi di ruang kelas bertujuan untuk mencapai hasil belajar yang diinginkan. Penerapan lima prinsip pembelajaran ramah anak sebagai berikut:

1. Demokratisasi dalam pembelajaran

Dalam pembelajaran sudah diterapkan nuansa demokratis. Guru memberi kebebasan berpikir kepada siswa sesuai dengan potensi dan kemampuannya. Bebas dari tekanan perasaan takut salah atau tidak mampu. Menghargai aktivitas belajar positif yang ditunjukkan siswa. Sebaliknya memberikan hukuman secara adil dan mendidik jika mereka melakukan aktivitas negatif dalam belajar.

2. Saling menghargai dalam aktivitas belajar

Dalam konsep Sekolah Ramah Anak, sebuah hubungan yang baik antara seorang guru dan siswa perlu dibentuk sebagai upaya untuk memperhatikan hak-hak anak. Anak perlu diberikan kebebasan dalam mengeluarkan pendapatnya dan mengakomodirnya dalam setiap penentuan kebijakan di dalam kelas maupun disekolah. Dari hasil hasil penelitian, hal yang ditemukan oleh peneliti di lapangan, bahwa di SD Negeri Lempuyangwangi, setiap pagi sebelum dimulainya kegiatan belajar mengajar di sekolah, guru menanyakan keadaan dan kabar kepada setiap anak didiknya, guru menampakkan rasa kepedulian kepada peserta didiknya, sehingga anak menjadi terbuka dan menceritakan tentang apa yang dialaminya dan yang dilakukannya pada hari kemarin kepada gurunya..

3. Penegakan disiplin belajar

Sekolah harus memiliki aturan dan tata tertib dalam proses belajar mengajar. Disiplin belajar harus dibuat dengan melibatkan siswa. Artinya siswa diberi kesempatan untuk memberikan berpendapat tentang aturan belajar serta sanksinya. Ketika terjadi pelanggaran disiplin belajar oleh siswa, guru perlu meminta kesepakatan kembali kepada siswa lain untuk memberikan sanksi kepada siswa yang melanggar disiplin belajar. Kendala yang sering dihadapi oleh para guru dalam proses penanaman kedisiplinan belajar adalah siswa cenderung mengikuti aturan yang berlaku apabila sudah ditegur dan di nasehati. Namun berselang beberapa waktu, siswa akan mengulangi tindakan yang sama kembali. Contoh, siswa yang sudah ditegur dan dinasehati karena membuat keributan di dalam kelas, kembali melakukan pelanggaran yang sama. Dengan memberikan sanksi kepada siswa, tidak luput dari upaya guru dalam menanamkan kedisiplinan kepada siswa. Namun, siswa tidak mengindahkan sanksi atau hukuman yang mereka terima. Kendala lainnya adalah tidak adanya guru Bimbingan Konseling di Sekolah Dasar, sehingga peran guru bimbingan konseling ini dirangkap oleh guru kelas.

4. Ruang kelas yang nyaman

Suasana belajar akan kondusif dan menyenangkan bila ruang belajar nyaman, bersih dan rapi. Lantai kelas bersih dari sampah dan kotoran tanah yang terbawa sepatu ke dalam kelas. Susunan meja dan kursi teratur. Ventilasi udara yang memadai. Gambar dan media yang tertata rapi di dinding kelas. Kondisi ini akan mempengaruhi mood belajar siswa. Dari hasil observasi didapatkan bahwa SDN Lempuyangwangi telah mengupayakan agar ruang kelas menjadi tempat yang nyaman untuk belajar diantaranya dengan membentuk regu piket, adanya pojok baca kelas serta ventilasi yang cukup. Disamping untuk mencipatakan suasana 
kelas yang menyenangkan, pojok baca ini juga sebagai upaya untuk meningkatkan minat membaca siswa. Pembuatan pojok baca kelas ini merupakan hasil kerjasama antara pihak sekolah dengan orang tua / wali siswa.

5. Metode pembelajaran yang sesuai

Pembelajaran ramah anak juga perlu diterapkan dengan penggunaan metode mengajar yang sesuai. Metode mengajar tak perlu yang eksklusif namun sesuai dengan karakter siswa, materi pelajaran, dan ketersediaan sarana dan prasarana belajar.

\section{Partisipasi Anak, orang tua, lembaga masyarakat, dunia usaha, pemangku kepentingan}

Salah satu komponen yang harus dipenuhi dalam implementasi Sekolah Ramah Anak adalah adanya partisipasi anak. Proses pembelajaran di SDN Lempuyangwangi menitikberatkan kepada hak setiap anak untuk menyatakan pendapatnya, menerima, mencari, dan memberikan informasi sebagai upaya pengembangan dirinya. Selain itu pembelajaran juga memberikan kesempatan kepada anak untuk menikmati pendidikan tanpa diskriminasi berdasarkan disabilitas, gender, suku bangsa, agama, dan latar belakang orang tua. Selain pembelajaran yang menyenangkan dan tidak membosankan bagi anak, pelibatan anak dalam pembuatan kebijakan dan peraturan di dalam konsep Sekolah Ramah Anak harus diperhitungkan. Karena sesuai dengan salah satu prinsip dalm konvensi hak anak yaitu menghargai hak anak, maka keterlibatan anak harus diutamakan agar anak tidak merasa tertekan dan merasa nyaman di sekolah. Jika peraturan dibuat tanpa adanya partisipasi anak maka hak-hak anak telah dilanggar dan dapat mengintimidasi mereka selama berada di sekolah.

Sekolah ramah anak akan bisa terwujud apabila pihak-pihak terkait serta pemangku kepentingan mau bahu-membahu melakukan berbagai upaya serta terjalin kerjasama yang harmonis. Partisipasi dari semua pihak sangat penting dalam mendukung program-program sekolah. Apabila partisipasi telah terpelihara dengan baik, maka sekolah tidak akan mengalami kesulitan yang berarti dalam mengembangkan berbagai jenis program, karena semua pihak telah memahami dan merasa bertanggung jawab terhadap mutu dan keberhasilan suatu program pendidikan yang akan dikembangkan pihak sekolah.

\section{Kesimpulan}

Berdasarkan hasil penelitian yang berjudul "Implementasi Sekolah Ramah Anak di SDN Lempuyangwangi” Peneliti mengkaji implementasi Program Sekolah Ramah Anak berdasarkan pada komponen-komponen sebagai berikut:

a) Adanya komitmen tertulis yang dapat dianggap kebijakan tentang Sekolah Ramah Anak. Pengimplementasian program Sekolah Ramah Anak di SDN Lempuyangwangi mengacu pada Panduan Sekolah Ramah Anak yang dikeluarkan oleh Deputi Tumbuh Kembang Anak Kementrian Pemberdayaan Perempuan dan Perlindungan Anak. Disamping itu juga berpedoman pada Peraturan Daerah Kota Yogyakarta nomor 1 tahun 2016 tentang Kota Layak Anak, Peraturan Walikota Yogyakarta nomor 49 tahun 2016 tentang Sekolah Ramah Anak serta Keputusan kepala Sekolah SDN Lempuyangwangi nomor 188/012/2019 tentang Pembentukan Tim Sekolah Ramah Aanak SDN Lempuyangwangi yang indikatorindikatornya tetap mengacu pada Panduan Sekolah Ramah Anak. Jadi sudah sesuai dengan indikator mengenai adanya komitmen tertulis tentang Sekolah ramah Anak.

b) Pelaksanaan proses pembelajaran yang ramah anak. Pelaksanaan proses pembelajaran yang ramah anak di SDN Lempuyangwangi berjalan dengan baik, hal itu bisa dilihat dari pelaksanaan program Sekolah Ramah Anak pada proses pembelajaran dilakukan dengan metode pembelajaran berbasis PAIKEM (Pembelajaran Aktif, Inovatif, Kreatif, Efektif, dan Menyenangkan) dan menerapkan 5 prinsip pembelajaran yang ramah anak yaitu 
demokratisasi dalam pembelajaran, saling menghargai dalam aktivitas belajar, penegakan disilpin belajar, ruang kelas yang nyaman, metode pembelajaran yang sesuai.

c) Partisipasi anak. Partisipasi anak bisa diwujudkan dengan baik. Bentuk partisipasi anak tidak hanya pada pelibatan anak dalam pembuatan dan perumusan kebijakan di sekolah tetapi lebih melihat pada peran siswa dalam keaktifannya berekspresi, bertanya, menjawab, berargumentasi, bahkan siswa diperkenankan untuk menginterupsi pada saat pendidik sedang menjelaskan. Bentuk partisipasi ini terlihat dari penataan ruang kelas, pembagian jadwal piket, kesepakatan hukuman, dan kebebasan untuk memilih ekstrakurikuler yang disukai.

d) Partisipasi orang tua, lembaga masyarakat, dunia usaha, pemangku kepentingan. Adanya partisipasi orang tua, lembaga masyarakat, dunia usaha, dan pemangku kepentingan sudah dilakukan dan berjalan dengan baik dengan menjalin kerjasama dengan orang tua, masyarakat sekitar, kepolisian, Puskesmas, Badan Penanggulangan Bencana Daerah (BPBD), dan Dinas Lingkungan Hidup (DLH) Kota Yogyakarta. Kerjasama dengan berbagai pihak dan instansi pemerintah sudah terjalin dengan baik sebagai upaya untuk mendukung pelaksanaan Sekolah Ramah Anak di SDN Lempuyangwangi.

\section{Daftar Pustaka.}

Abd. Rahman Assegaf. 2004. Pendidikan Tanpa Kekerasan Tipologi Kondisi,. Kasus dan Konsep. Yogyakarta: Tiara Wacana Yogya

Agustino, Leo. 2006. Dasar-Dasar Kebijakan Publik. Bandung: CV. Alfabeta.

Ahmad Rohani, HM, 2004. Pengelolaan Pengajaran. Jakarta: Asdimahasatya

Deputi Tumbuh Kembang Anak. 2015. Panduan Sekolah ramah Anak. Jakarta: Kementrian Pemberdayaan Perempuan dan Perlindungan Anak republik Indonesia

Departemen Pendidikan dan Kebudayaan Republik Indonesia. 1989. Kamus Besar Bahasa Indonesia. Jakarta:Balai Pustaka

Dimyati dan Mujiono. 1996. Belajar dan Pembelajaran, Jakarta: PT. Rineka Cipta

Eveline Siregar \& Hatini Nara. 2010. Teori Belajar dan Pembelajaran. Bogor: Ghalia Indonesia

Florence Beetlestone, 2013. Creative Learning: Strategi Pembelajaran Untuk Melesatkan Kreatifitas Siswa, Bandung: Nusa Media

George C Edward III. 1980. Implementation Public Policy. Congressional Quarterly Press. Washington.

Hernowo, 2002. Belajar Akan Efektif Kalau Anda Dalam Keadaan "Fun”, Terj. Word ++ Translation Service, Bandung: Kaifa

Mami Hajaroh,Rukiyati, L.Andriyani Purwastuti, Bambang Saptono, 2017. Analisis Kebijakan Sekolah Ramah Anak di kawasan Pesisir Wisata. Yogyakarta: Penerbit ANDI

Miles, Mattew B dan A. Michael Huberman. 2007. Analisis Data Kualitatif, Buku sumber tentang metode-metode baru. Jakarta: Universitas Indonesia Press.

Nurdyansyah, N., \& Andiek Widodo. 2015. Inovasi Teknologi Pembelajaran. Sidoarjo: Nizamia Learning Center

Randall B. Ripley \& Grace A. Franklin. 1986. Policy Implementation and Bureaucracy. Chicago.The Dorsey Press

Winarno, Budi, 2005. Teori dan Proses Kebijakan Publik. Yogyakarta: Media Presindo.

Peraturan Menteri Negara Pemberdayaan Perempuan dan Perlindungan Anak Republik Indonesia Nomor 8 tahun 2014 tentang Kebijakan Sekolah Ramah Anak

Peraturan Menteri Pemberdayaan Perempuan dan Perlindungan Anak Republik Indonesia Nomor 11 tahun 2011 tentang Kebijakan Pengembangan Kabupaten/Kota Layak Anak (KLA) 
Peraturan Menteri Pemberdayaan Perempuan dan Perlindungan Anak Republik Indonesia Nomor 12 tahun 2011 tentang Indikator Pengembangan Kabupaten/Kota Layak Anak (KLA)

Peraturan Walikota Yogyakarta Nomor 1 Tahun 2016 tentang Kota Layak Anak

Galuh Mentari Putri. 2020. Implementasi Sekolah Ramah Anak di Sekolah Dasar Negeri Model Kota Malang. Universitas Islam Negeri Maulana Malik Ibrahim: Skripsi

Ranti Eka Utari. 2016. Implementasi Sekolah Ramah Anak di Sekolah Menengah Pertama Negeri 1 Tempuran Kabupaten Magelang. Universitas Negeri Yogyakarta: Skripsi

Zaenuddin. 2018. Implementasi Program Sekolah Ramah Anak (SRA) Study kasus pada SD Negeri I Ampenan Kota Mataram. Universitas Islam Negeri Mataram: Skripsi

Muniroh, J. (2017). Manajemen Pendidikan Dan Tenaga Kependidikan Di Madrasah Aliyah Negeri Kota Yogyakarta. Jurnal Akuntabilitas Manajemen Pendidikan. Vol. 5 No. 2. PISSN 2337-7895, e-ISSN 2461-0550 (Diakses tanggal 15 Desember 2020)

Nashih Nashrulloh. 2019. KPAI dorong percepatan realisasi Sekolah Ramah Anak. https://www.republika.co.id/berita/pendidikan/eduaction/19/05/02/pqvqe6320 (diakses tanggal 17 September 2020).

Uda Awak. 2015.Penerapan Pembelajaran Ramah Anak. https://www.matrapendidikan.com/2015/11/penerapan-pembelajaran-ramah-anak.html (diakses tanggal 17 September 2020) 